\title{
The Utilization of Wheat Germ in Burger Preparation
}

\author{
*Mahmoud F. S. Kadous , ** Saad A. Mahgoub and ** Walid, M. Shehata \\ *Meat and Fish Research Department and **Crops Technology Research. Department, Food Technology \\ Research Institute, Agriculture Research Center, Giza, Egypt.
}

\begin{abstract}
The present study was aimed to investigate the possibility of utilizing wheat germ extrudate in beef burger preparation as a substitution of beef meat by $(5,10,15$ and $20 \%$ levels). Chemical, physical and sensory characteristics of prepared burger were determined. By increasing the wheat germ extrudate levels, carbohydrate, fiber and ash were significantly increased, while total protein and fats were significantly decreased. Also, by increasing the added levels of wheat germ extrudates, $\mathrm{Mg}, \mathrm{K}, \mathrm{Mn}, \mathrm{Zn}$ and $\mathrm{P}$ were significantly increased while; $\mathrm{Fe}, \mathrm{Na}$ and $\mathrm{Ca}$ were significantly decreased. The substitution of beef meat with wheat germ extrudate significantly enhanced the chemical and physical quality attributes of produced burger (TVN, TBA, pH, WHC and plasticity). The best Quality attributes were achieved at $10 \%$ level compared to control. So, we recommend adding wheat germ extrudate at $10 \%$ level in beef burger preparation.
\end{abstract}

Keywords: Beef burger, extruded wheat germ, Chemical and physical quality attributes and sensory evaluation

\section{Introduction}

Wheat germ is a part of the kernel, approximately $2.5 \%$ in total product. It is a byproduct of the flour milling industry which appears a potential source of total proteins and is reported to be competable to animal total proteins for human consumption besides being an excellent source of tocopherol, B group vitamins and oil. Also, it contains 23 nutrients and has more nutrient per gram than any other vegetable or grain (Kalpana and Vali, 2009 and Sahar, 2012)

Wheat germ contains moisture (5.1-5.13\%), total protein $(18.8-24.81 \%)$, ash $(1.4-1.65 \%)$, fat $(6.55-10.1 \%)$, fiber $(1.4-1.48 \%)$ and carbohydrates (60.4-64.4\%). Raw wheat germ contain $10 \%$ oil is mainly used in nutrition and cosmetic industries as a source of oil (Kahlon, 1989). Wheat germ contains $28 \%$ total protein and has more total protein than can be found in most meat products (Brouce, et al. 1997). Wheat germ contains potassium and iron higher than any other grain. Also quantities of calcium, zinc, magnesium and vitamins $\mathrm{A}, \mathrm{B}_{1}, \mathrm{~B}_{2}$ and $\mathrm{E}$ were found in wheat germ (Fraser, et al. 1992) and (Spiller and Jenkins, 1992).

Meat industry is continues updating to improve eating quality characteristics and palatability attributes which are the major determine of consumer acceptance and preference. The retail sale of beefburger is a big business. High meat prices prompted the meat producers in Egypt to produce various meat brands extended with non-meat ingredients. However maintaining the nutritional contribution organoleptic and textural properties of meat products is matter of challenge, which necessitates more effort to protect the product integrity, taste, flavor and textural sensory attributes (Gehan and Emara, 2010).

Non- meat total protein were added to improve water binding stabilize fat. Vegetable products are added to raw or cooked meat products to improve its functional properties, nutritional value and sensory qualities. Most of meat products are rich in fat, but deficient in complex carbohydrates (Serdaroglu and Degirmencioglu, 2004) and (Turhan, et al. 2007).

Vegetable products play an important role in human nutrition as a provide essential minerals and vitamins (Yue, 2001). It can also be used to replace part of the animal fat with its hydrating capacity and replace part of the animal meat with vegetable products considerably decrease the final cost of meat products (Mizutani and Hashimoto, 2004). Also, it serve as, fillers, fat replacers and source of dietary fibers and natural antioxidants in meat system (Hedrick, et al. 1994).

The present study was aimed to investigate the possibility of utilizing wheat germ extrudate in beef burger preparation as a substitution of beef meat by $(5,10,15$ and $20 \%$ levels $)$ and maintain the quality attributes, Chemical, physical and sensory characteristics of beef burger.

\section{Materials and Methods}

Raw materials.

Refrigerated beef meat was obtained from supper market, Egypt. Immediately after purchasing, samples were transported using ice box to the laboratory of Meat and Fish Technology, Food Technology Research Institute, Agriculture Research Center, Giza, Egypt. Other ingredients such as soy protein, wheat germ, salt, onion, spices, garlic, starch were purchasing from local market at Giza.

\section{Adjusting moisture content of wheat germ before extrusion.}

The amount of water was added to bring 1000 grams of sample to the desire moisture level 
extrusion and it was calculated according to the following equation:

(Water added $=$ moisture desired \%-moisture samples x $10^{3} / 100$ - moisture desired \%)

.Water was added gradually to the samples and mixed for 5 minutes by mechanical mixer. The samples were placed in plastic bags and kept for 24 hrs at $4^{\circ} \mathrm{C}$ to equilibrate the moisture according to (EL-Dash, 1985).

\section{Extrusion conditions.}

A Model BC21co-rotating Clextral twin screw extruder with intermeshing screws (Clextral, Firminy Cedex, France) and $3 \mathrm{~mm}$ diameter circular die was used. The unit was operated at flow rate of $(12 \mathrm{~kg}$ $/ \mathrm{hr}$ ) and $400 \mathrm{rpm}$ screw speed. Temperature profile in the four barrel sections from the feed end were set at $150^{\circ} \mathrm{C}$ by according to (Supat, et al. 2008).

\section{Preparation of burger.}

Refrigerated beef meat was manually cut using band saw and minced through ( $24 \mathrm{~mm}$ plate)and divided into four formulas and control. Mix the ingredients of control formula=(beef meat $78 \%$, soy protein $10 \%$, minced garlic $1 \%$, minced onion $4.45 \%$, salt $2 \%$, spices $2 \%$, white pepper $0.5 \%$, Na pyrophosphate $0.5 \%$, cumin $1 \%$ and starch $1 \%$. Formula $_{1}$ (beef meat $73 \%$, wheat germ $5 \%$ ), Formula 2 (beef meat $68 \%$, wheat germ $10 \%$ ), Formula $_{3}$ (beef meat $63 \%$, wheat germ $15 \%$ ) and Formula 4 (beef meat $58 \%$, wheat germ 20\%) and the other ingredients were added to all formulas with the same level. The formulas were separately then formed into discs of $100 \mathrm{~g}$, kept frozen at $-18 \mathrm{C}^{\circ}$, samples were then taken for analysis.

\section{Chemical analysis.}

Proximate analysis including moisture, total protein, fat, ash and fiber were carried out according to the methods of (AOAC, 2005). Carbohydrates content was calculated by difference. Magnesium, sodium, potassium, manganese, iron, calcium and zinc were determined according to (AOAC, 2005). Perkin Elmer (Model 3300, USA) Atomic Absorption Spectrophotometer was used to determine these minerals.

Total phosphorous was determined using common colorimetric method described by (AOAC,1995).

Physiochemical evaluation.

Total volatile nitrogen (T.V.N) was determined according to (Winton and Winton, 1958), thiobarbituric acid (T.B.A) value was determined according to (Pearson, 1970) and $\mathrm{pH}$ value was determined to (Aitken, et al. 1962). The water holding capacity (W.H.C.) and plasticity were measured by filter press methods of (Soloviev, 1966). Cooking loss of samples was calculated as percentage of weight change from raw to cooked state.

\section{Sensory evaluation.}

Sensory evaluation was determined according to (Suderman, et al. 1981). Immediately after preparing of burger, samples were prepared by frying in plant oil for (5-10 min) and subjected to member's trained sensory panel to find out the formulas that have more palatability by evaluating color, odor, texture and overall acceptability of these formulas.

\section{Statistical analysis.}

The obtained data were exposed to analysis of variance followed by multiple comparisons $=$ between means $\quad(\mathrm{P} \leq 0.05)$ applying LSD. The analysis was carried out using the PRO ANOVA procedure of Statistical Analysis System (SAS Program, 1996).

\section{Results and Discussion}

\section{Chemical composition of raw and extruded wheat germ.}

Chemical composition results of wheat germ (raw and extrudate) are shown in Table (1). The data showed that there was a significant difference $(\mathrm{P} \leq 0.05)$ between raw and extrudate wheat germ. Where, showed that moisture, total protein, fat, fiber, ash and total carbohydrates were (7.4 and 9.43\%), (30.8 and 29.5\%), (8.23 and $7.64 \%),(4.3$ and $3.76 \%),(4.63$ and $5.16 \%)$ and (44.54 and $44.51 \%)$, respectively. The results are in accordance with those reported by (Al-Hooti, $\boldsymbol{e} \boldsymbol{t} \boldsymbol{a l}$. 2002). They mentioned that proximate composition of wheat germ were moisture $8 \%$, total protein $30 \%$, fat $9 \%$, fiber $3.5 \%$, ash $4 \%$ and total carbohydrates $45.5 \%$.

Table 1.Chemical composition of wheat germ (raw and extruded). (On wet weight basis)

\begin{tabular}{lccc}
\hline & \multicolumn{2}{c}{ Wheat germ $(\mathrm{g} / 100 \mathrm{~g})$} & \multicolumn{1}{c}{$L S D$} \\
\cline { 2 - 3 } \multicolumn{1}{c}{ Properties } & Raw & Extruded & 0.5152 \\
Moisture & $7.4 \pm 0.2^{\mathrm{b}}$ & $9.43 \pm 0.9^{\mathrm{a}}$ & 0.8972 \\
Total protein & $30.8 \pm 1.5^{\mathrm{a}}$ & $29.5 \pm 0.5^{\mathrm{b}}$ & 0.8277 \\
Fat & $8.23 \pm 1.45^{\mathrm{a}}$ & $7.64 \pm 0.25^{\mathrm{b}}$ & 0.4034 \\
Fiber & $4.3 \pm 1.2^{\mathrm{a}}$ & $3.76 \pm 0.15^{\mathrm{b}}$ & 0.5235 \\
Ash & $4.63 \pm 0.21^{\mathrm{b}}$ & $5.16 \pm 0.85^{\mathrm{a}}$ & 0.0358 \\
Total carbohydrates & $44.54 \pm 0.05^{\mathrm{a}}$ & $44.51 \pm 0.01^{\mathrm{a}}$ & \\
\hline
\end{tabular}

Values are means for $3 \pm$ SD. There is significant difference between two means have the letter $(\mathrm{P}>0.05)$. 


\section{Mineral contents of raw and extruded wheat germ.}

Data presented in Table (2) showed that, the wheat germ is a good source of mineral such as potassium and phosphorus. The data in the same table showed significant differences between raw and extrudate wheat germ of the minerals contents. Where, wheat germ raw and extrudate were containing magnesium (303 and $294 \mathrm{mg} / 100 \mathrm{~g}$ ), sodium (93.3 and $91.7 \mathrm{mg} / 100 \mathrm{~g}$ ), potassium (954and $934 \mathrm{mg} / 100 \mathrm{~g})$, manganese (13 and $11 \mathrm{mg} / 100 \mathrm{~g}$ ), iron
(9 and $8.7 \mathrm{mg} / 100 \mathrm{~g}$ ), calcium(47 and $42 \mathrm{mg} / 100 \mathrm{~g}$ ), zinc (8.4 and $9.2 \mathrm{mg} / 100 \mathrm{~g})$ and phosphorus (639 and $632 \mathrm{mg} / 100 \mathrm{~g})$,respectively. These data indicated that thermal extrusion lead to a slight reduction of the minerals. The results are in accordance with those reported by (Sahar, 2012) who mentioned that proximate mineral of wheat germ magnesium $(301 \mathrm{mg} / 100 \mathrm{~g})$ ), potassium (1039 $\mathrm{mg} / 100 \mathrm{~g})$,iron $\quad(7.2 \mathrm{mg} / 100 \mathrm{~g}), \quad$ calcium(46 $\mathrm{mg} / 100 \mathrm{~g})$,zinc $(8.5 \mathrm{mg} / 100 \mathrm{~g})$ and phosphorus (645 $\mathrm{mg} / 100 \mathrm{~g}$

Table 2 . Mineral contents of raw and extruded wheat germ.

\begin{tabular}{lccc}
\hline & \multicolumn{2}{c}{ Wheat germ $(\mathrm{Mg} / 100 \mathrm{~g})$} & \\
\cline { 2 - 3 } Prosperities & Raw & Extruded & 1.925 \\
\hline Magnesium & $303 \pm 4.2^{\mathrm{a}}$ & $294 \pm 2.1^{\mathrm{b}}$ & 2.138 \\
Sodium & $93.3 \pm 3.8^{\mathrm{a}}$ & $91.7 \pm 1.5^{\mathrm{b}}$ & 1.654 \\
Potassium & $954 \pm 5.1^{\mathrm{a}}$ & $934 \pm 2.5^{\mathrm{b}}$ & 0.584 \\
Manganese & $13 \pm 2.0^{\mathrm{a}}$ & $11 \pm 1.0^{\mathrm{b}}$ & 0.736 \\
Iron & $9 \pm 1.0^{\mathrm{a}}$ & $8.7 \pm 0.5^{\mathrm{a}}$ & 0.462 \\
Calcium & $47 \pm 1.5^{\mathrm{a}}$ & $42 \pm 0.53^{\mathrm{b}}$ & 0.524 \\
Zinc & $8.4 \pm 0.5^{\mathrm{a}}$ & $9.2 \pm 0.2^{\mathrm{a}}$ & 0.762 \\
Phosphorus & $639 \pm 2.5^{\mathrm{a}}$ & $632 \pm 1.5^{\mathrm{b}}$ & \\
\hline
\end{tabular}

Values are means for $3 \pm$ SD. There is significant difference between two means have the letters $(\mathrm{P} \leq 0.05)$.

\section{Chemical composition of burger substituted with extruded wheat germ.}

Data in Table (3) indicated that moisture level in the control sample is higher than the other formulas and there were significant differences between all formulas There is no significant difference between two means have the letter $(\mathrm{P}>0.05)$. Where, the protein and fat simply reduced, ash and fiber simply increased, by increasing the amount of wheat extruded wheat germ in the studied formulas carbohydrates were significantly increased in compared to control. This may be due to wheat germ contains a high percentage of carbohydrates $50.49 \%$ proximately (kalpana and Vali, 2009).

Table 3. Chemical composition of burger substituted with extruded wheat germ $(\mathrm{g} / \mathrm{loog})$. (On wet weight basis).

\begin{tabular}{|c|c|c|c|c|c|c|}
\hline Prosperities & Control & $\mathrm{F}_{1}$ & $\mathrm{~F}_{2}$ & $\mathrm{~F}_{3}$ & $\mathrm{~F}_{4}$ & $L S D$ \\
\hline \multirow{2}{*}{ Moisture } & 66.9 & 61.6 & 60.7 & 59.3 & 58.2 & \multirow{2}{*}{0.0236} \\
\hline & $\pm 0.5^{\mathrm{a}}$ & $\pm 0.41^{\mathrm{b}}$ & $\pm 0.32^{\mathrm{c}}$ & $\pm 0.25^{\mathrm{d}}$ & $\pm 0.15^{\mathrm{e}}$ & \\
\hline \multirow{2}{*}{ Total protein } & 21.6 & 21.5 & 20.4 & 20.2 & 19.4 & \multirow{2}{*}{0.0933} \\
\hline & $\pm 0.35^{\mathrm{a}}$ & $\pm 0.34^{\mathrm{a}}$ & $\pm 0.23^{\mathrm{b}}$ & $\pm 0.21^{\mathrm{b}}$ & $\pm 0.15^{\mathrm{c}}$ & \\
\hline \multirow{2}{*}{ Fat } & 3.4 & 3.24 & 3.15 & 2.83 & 2.45 & \multirow{2}{*}{0.0261} \\
\hline & $\pm 0.22^{\mathrm{a}}$ & $\pm 0.18^{\mathrm{b}}$ & $\pm 0.16^{\mathrm{b}}$ & $\pm 0.12^{\mathrm{c}}$ & $\pm 0.08^{\mathrm{d}}$ & \\
\hline \multirow{2}{*}{ Ash } & 2.73 & 3.15 & 3.34 & 3.55 & 3.66 & \multirow{2}{*}{0.0335} \\
\hline & $\pm 0.03^{\mathrm{e}}$ & $\pm 0.07^{\mathrm{d}}$ & $\pm 0.11^{\mathrm{c}}$ & $\pm 0.15^{\mathrm{b}}$ & $\pm 0.19^{\mathrm{a}}$ & \\
\hline \multirow{2}{*}{ Fiber } & 1.17 & 1.23 & 1.47 & 1.73 & 1.94 & \multirow{2}{*}{0.0230} \\
\hline & $\pm 0.04^{\mathrm{e}}$ & $\pm 0.08^{\mathrm{d}}$ & $\pm 0.12^{\mathrm{c}}$ & $\pm 0.15^{\mathrm{b}}$ & $\pm 0.21^{\mathrm{a}}$ & \\
\hline Total & 4.2 & 9.28 & 10.94 & 12.39 & 14.35 & \multirow{2}{*}{0.0195} \\
\hline Carbohydrates & $\pm 0.1^{\mathrm{e}}$ & $\pm 0.12^{\mathrm{d}}$ & $\pm 0.36^{\mathrm{c}}$ & $\pm 0.06^{\mathrm{b}}$ & $\pm 0.26^{\mathrm{a}}$ & \\
\hline
\end{tabular}

Values are means for $3 \pm$ SD. There is significant difference between the letters $(\mathrm{P}>0.05)$.

\section{Mineral contents of burger substituted with extruded wheat germ.}

Data in Table (4) represents the mineral contents burger substitution with extruded wheat germ. It could be noticed that the level of magnesium, potassium, manganese, zinc and phosphorus contents were significantly increased, with the adding level of wheat germ, where, that F4 had the highest content of magnesium, potassium, manganese, iron, zinc and phosphorus followed by F3, 2, 1 and control respectively.

While the level of sodium, iron and calcium decreased with increasing the added level of extruded wheat germ. This may be due to wheat germ is a very rich with potassium, zinc and phosphorus (Fraser, et al. 1992) and (Spiller and Jenkins, 1992). Also, may be due to decreasing the moisture content and increasing of the ash content as shown in the table (4) as results of increasing of addition wheat germ. 
Table 4. Mineral contents of burger substituted with extruded wheat germ. (mg/100g).

\begin{tabular}{|c|c|c|c|c|c|c|}
\hline Elements & Control & $\mathrm{F}_{1}$ & $\mathrm{~F}_{2}$ & $\mathrm{~F}_{3}$ & $\mathrm{~F}_{4}$ & $L S D$ \\
\hline \multirow{2}{*}{ Magnesium } & 81.4 & 85.5 & 89.2 & 92.6 & 94.7 & \multirow[b]{2}{*}{0.6894} \\
\hline & $\pm 1.95^{\mathrm{d}}$ & $\pm 0.86^{\mathrm{c}}$ & $\pm 2.1^{\mathrm{b}}$ & $\pm 1.1^{\mathrm{a}}$ & $\pm 0.96^{\mathrm{a}}$ & \\
\hline \multirow{2}{*}{ Sodium } & 196.6 & 192.5 & 185.5 & 132.6 & 111.4 & \multirow{2}{*}{0.5951} \\
\hline & $\pm 2.89^{\mathrm{a}}$ & $\pm 2.1^{\mathrm{b}}$ & $\pm 1.22^{\mathrm{c}}$ & $\pm 0.56^{\mathrm{d}}$ & $\pm 1.87^{\mathrm{e}}$ & \\
\hline \multirow{2}{*}{ Potassium } & 225.6 & 232.5 & 266.9 & 289.1 & 296.5 & \multirow{2}{*}{0.1500} \\
\hline & $\pm 1.2^{\mathrm{e}}$ & $\pm 0.75^{\mathrm{d}}$ & \pm 1.35 & $\pm 1.56^{\mathrm{b}}$ & $\pm 0.85^{\mathrm{a}}$ & \\
\hline \multirow{2}{*}{ Manganese } & 18.8 & 19.1 & 28.2 & 43.8 & 57.7 & \multirow{2}{*}{0.0281} \\
\hline & $\pm 0.71^{\mathrm{e}}$ & $\pm 0.46^{\mathrm{d}}$ & $\pm 0.7^{\mathrm{c}}$ & $\pm 0.45^{\mathrm{b}}$ & $\pm 0.44^{\mathrm{a}}$ & \\
\hline \multirow{2}{*}{ Iron } & 13.4 & 13.1 & 12.7 & 12.2 & 11.8 & \multirow{2}{*}{0.0262} \\
\hline & $\pm 0.2^{\mathrm{a}}$ & $\pm 0.3^{\mathrm{b}}$ & $\pm 0.22^{\mathrm{c}}$ & $\pm 0.55^{\mathrm{d}}$ & $\pm 0.5^{\mathrm{e}}$ & \\
\hline \multirow{2}{*}{ Calcium } & 373 & 362.3 & 345.3 & 326 & 312.3 & \multirow{2}{*}{0.3489} \\
\hline & $\pm 3.0^{\mathrm{a}}$ & $\pm 2.51^{\mathrm{b}}$ & $\pm 2.52^{\mathrm{c}}$ & $\pm 3.0^{\mathrm{d}}$ & $\pm 2.54^{\mathrm{e}}$ & \\
\hline \multirow{2}{*}{ Zinc } & 87.5 & 91.7 & 103 & 123 & 136 & \multirow{2}{*}{0.3941} \\
\hline & $\pm 0.36^{\mathrm{e}}$ & $\pm 1.5^{\mathrm{d}}$ & $\pm 2.0^{\mathrm{c}}$ & $\pm 3.0^{\mathrm{b}}$ & $\pm 4.0^{\mathrm{a}}$ & \\
\hline \multirow{2}{*}{ Phosphorus } & 165 & 171 & 178 & 184 & 192 & \multirow{2}{*}{0.2572} \\
\hline & $\pm 2.7^{\mathrm{e}}$ & $\pm 1.2^{\mathrm{d}}$ & $\pm 1.6^{\mathrm{c}}$ & $\pm 1.9^{\mathrm{b}}$ & $\pm 2.4^{\mathrm{a}}$ & \\
\hline
\end{tabular}

Values are means for $3 \pm$ SD. There is significant difference between the letters $(\mathrm{P}>0.05)$

Chemical quality attributes of burger substituted with extruded wheat germ.

Results found in Table (5) showed chemical quality attributes of burger for with extruded wheat germ and control, it could be noticed that control recorded the highest value of T.V.N. followed by formula 1, 2, 3 and 4 respectively. So may be there is a direct between total protein content and T.V.N. level.

According to (Egyptian Organization Standardization, 2005) minced meat mixed with soya bean total protein should not be contained T.V.N. more than $20 \mathrm{mg} / 100 \mathrm{~g}$ (w.w). It is clear that this level not exceeded this amount as all samples had less T.V.N. than the allowance. It could be noticed that, the control had the highest value of $\mathrm{pH}$ followed by formula 1, 2, 3 and 4 respectively. This may be confirmed by the relatively higher T.V.N.
Table (5) of control than formula1, 2, 3 and 4, this may be explain in the higher $\mathrm{PH}$ value for control than the letter formula (Sanchez-Alonso, et al. 2007).

It could be noticed that control recorded the highest value of T.B.A followed by formula 1, 2, 3, 4 respectively. This may be attributed to a higher fat content Table (5) may be there is a direct correlation between fat content and T.B.A value According to (Egyptian Organization Standardization, 2005) minced meat mixed with soya bean total protein should not be contained T.B.A more than $0.9 \mathrm{mg}$ malonaldehyde $/ \mathrm{kg}$ (w.w.). It is clear that this level did not exceeded also, all samples were below the permitted. The data in the same table showed that there are significant differences between the control and the rest of the formulas in the chemical quality attributes.

Table 5. Chemical quality attributes of beef burger substituted with extruded wheat germ (On wet weight basis).

\begin{tabular}{|c|c|c|c|c|c|c|}
\hline Prosperities & Control & F1 & $\mathrm{F} 2$ & F3 & F4 & $L S D$ \\
\hline T.V.N. & $\begin{array}{c}11.3 \\
\pm 0.3^{\mathrm{a}}\end{array}$ & $\begin{array}{c}10.9 \\
\pm 0.21^{\mathrm{ab}}\end{array}$ & $\begin{array}{c}10.7 \\
\pm 0.15^{\mathrm{b}}\end{array}$ & $10.4 \pm 0.1^{\mathrm{c}}$ & $\begin{array}{c}10.1 \\
\pm 0.1^{\mathrm{c}}\end{array}$ & 0.0419 \\
\hline $\mathrm{pH}$ & $\begin{array}{c}6.32 \\
\pm 0.08^{\mathrm{a}}\end{array}$ & $\begin{array}{c}6.3 \\
\pm 0.06^{\mathrm{b}}\end{array}$ & $\begin{array}{c}6.25 \\
\pm 0.04^{\mathrm{c}}\end{array}$ & $6.21 \pm 0.07^{\mathrm{d}}$ & $\begin{array}{c}6.18 \\
\pm 0.03^{\mathrm{e}}\end{array}$ & 0.0182 \\
\hline T.B.A. & $\begin{array}{c}0.292 \\
\pm 0.009^{\mathrm{a}}\end{array}$ & $\begin{array}{c}0.283 \\
\pm 0.006^{\mathrm{b}}\end{array}$ & $\begin{array}{c}0.278 \\
\pm 0.003^{\mathrm{c}}\end{array}$ & $\begin{array}{c}0.255 \\
\pm 0.007^{\mathrm{d}}\end{array}$ & $\begin{array}{l}0.231 \\
\pm 0.01^{\mathrm{e}}\end{array}$ & 0.0024 \\
\hline
\end{tabular}

Values are means for $3 \pm$ SD. There is significant difference between the letters $(\mathrm{P}>0.05)$.

T.V.N. : Total volatile nitrogen $(\mathrm{mg} / 100 \mathrm{mg})$

T.B.A. : Thiobarbituric acid (mg malonaldehyde/kg)

\section{Physical quality attributes of burger substituted with extruded wheat germ.}

From data presented in table (6) It could be noticed that formula (4) recorded the best value of Water Holding capacity and followed by formula 3, 2, 1 and control respectively, so maybe there is reflection correlation between water holding capacity and fat content table (1), it is known that fat is hydrophobic substance water repelling and do not bland with water with emulsifying, also maybe there is due to the high percentage of carbohydrates, which increased by increasing addition of wheat germ, where that carbohydrate works as a binder, where there is positive relationship between carbohydrate and water holding capacity.

From the obtained data presented in the same Table (6) plasticity (as indicator for texture) was completely affected by the level of water holding 
capacity, therefore, plasticity of formula (4) was the best value (due to it had the best value for water holding capacity) followed by formula 4, 3, 2, 1and control.

From the same Table (6) It could be noticed that cooking loss (\%) of formula (4) was the best value (the most low) followed by F 3, 2, 1 and control. This was also in accordance reverse with the level of water holding capacity indicating that the better of water holding capacity the lower of the cooking loss was found. The data in the same table showed that there are significant differences between the control and the rest of the formulas in the physical quality attributes.

These results are similar with those reported by (Anae and Josefphf, 1996) who found a quality characteristics of ground beef patties, supplemented with hydrated wheat germ total protein flour at levels 2.0, 3.5, and $5.0 \%$ were studied. Water holding capacity decreased and $\mathrm{pH}$ increased with addition of water activity was not affected. Supplemented beef patties had lower cooking losses and changes in diameter and higher yields than control patties. Substitution beef patties exhibited lower shear force and compression values than all-meat patties.

Table 6. Physical quality attributes of burger substituted with extruded wheat germ.

\begin{tabular}{lllllll}
\hline Prosperities & Control & F1 & F2 & F3 & F4 & LSD \\
\hline W.H.C. & 5.1 & 4.6 & 3.63 & 3.1 & 2.23 & 0.1636 \\
$\left(\mathrm{Cm}^{2} / 0.3 \mathrm{gm}\right)$ & $\pm 0.3^{\mathrm{a}}$ & $\pm 0.4^{\mathrm{a}}$ & $\pm 0.15^{\mathrm{b}}$ & $\pm 0.2^{\mathrm{b}}$ & $\pm 0.3^{\mathrm{c}}$ & \\
Plasticity & 6.2 & 6.4 & 6.93 & $7.2 \pm 0.1^{\mathrm{a}}$ & 7.5 & $\pm 0.2^{\mathrm{a}}$ \\
$\left(\mathrm{Cm}^{2} / 0.3 \mathrm{gm}\right)$ & $\pm 0.16^{\mathrm{c}}$ & $\pm 0.1^{\mathrm{c}}$ & $\pm 0.45^{\mathrm{b}}$ & & 0.2095 \\
Cook in loss & 28.3 & 27 & 25.6 & 23.5 & 18.7 & 0.4115 \\
\hline
\end{tabular}

Values are means for $3 \pm$ SD. There is significant difference between the letters $(\mathrm{P}>0.05)$.

W.H.C.: Water Holding capacity

\section{Sensory evaluation of burger substituted with extruded wheat germ.}

Sensory evaluation score (color, taste, odor, texture and overall acceptability) were evaluated by the panelists burger in Table (7). From the table (7) the results showed that the formula (2) gave the highest total score $79.7 \%$, followed by yellow Meanwhile, formula (4) gave the lowest total score $71.86 \%$ mean while control recorded $87.36 \%$.

From the obvious results, it could be recommended that the best substitution level $10 \%$ from formulas (beef meat (68\%), wheat germ (10\%), soy total protein $(10 \%)$, minced garlic $(1 \%)$, minced onion $(4.45 \%)$, salt $(2 \%)$, specie $(2 \%)$, white pepper $(0.5 \%), \mathrm{Na}$ pyrophosphate $(0.5 \%)$, cumin $(1 \%)$ and starch $(1 \%)$ ) these ratios appears improved the nutritional value and sensory qualities of burger produced. No significant differences between formula (2) and formula (1) with compared control, formula (2) was the highest scores panelists, nutrition value and quality.

Table 7. Sensory evaluation of burger substituted with extruded wheat germ.

\begin{tabular}{lcccccc}
\hline Panelists & Control & $\mathrm{F}_{1}$ & $\mathrm{~F}_{2}$ & $\mathrm{~F}_{3}$ & $\mathrm{~F}_{4}$ & LSD \\
\hline \multirow{2}{*}{ Color } & 17.93 & 16.71 & 16.71 & 16.86 & 15.86 & 1.4924 \\
& $\pm 1.44^{\mathrm{a}}$ & $\pm 1.68^{\mathrm{ab}}$ & $\pm 1.27^{\mathrm{ab}}$ & $\pm 2.18^{\mathrm{ab}}$ & $\pm 2.88^{\mathrm{b}}$ & \\
Taste & 17.36 & 15.29 & 15.57 & 14.14 & 13.14 & 1.4228 \\
& $\pm 1.34^{\mathrm{a}}$ & $\pm 2.16^{\mathrm{b}}$ & $\pm 1.78^{\mathrm{b}}$ & $\pm 2.28^{\mathrm{bc}}$ & $\pm 1.70^{\mathrm{c}}$ & \\
Oder & 17.64 & 16.36 & 16.14 & 15.78 & 15.29 & 1.6784 \\
& $\pm 1.78^{\mathrm{a}}$ & $\pm 2.64^{\mathrm{ab}}$ & $\pm 1.53^{\mathrm{ab}}$ & $\pm 3.79^{\mathrm{b}}$ & $\pm 2.43^{\mathrm{b}}$ & \\
Texture & 16.86 & 15.14 & 15.42 & 15.28 & 14.14 & 1.5928 \\
Overall & $\pm 1.35^{\mathrm{a}}$ & $\pm 1.70^{\mathrm{ab}}$ & $\pm 2.14^{\mathrm{ab}}$ & $\pm 2.78^{\mathrm{ab}}$ & $\pm 3.28^{\mathrm{b}}$ & \\
acceptability & 17.57 & 15.86 & 15.86 & 15.43 & 13.43 & 1.2621 \\
Total score & $\pm 3.09^{\mathrm{a}}$ & $\pm 1.43^{\mathrm{b}}$ & $\pm 1.46^{\mathrm{b}}$ & $\pm 1.41^{\mathrm{b}}$ & $\pm 2.83^{\mathrm{c}}$ & \\
\hline Vaas & 87.36 & 79.36 & 79.70 & 77.49 & 71.86 & ------- \\
\hline
\end{tabular}

Values are means for $10 \pm$ SD. There is significant difference between the letters $(\mathrm{P}>0.05)$.

\section{Conclusions}

It can be using extruded wheat germ as replacement of part beef meat at different levels with maintain the quality attributes, Chemical, physical and sensory characteristics of beef burger.

From the obtained results, it can be recommended that the best replacement level in beef meat with extruded wheat germ was $10 \%$ F $2,68 \%$ beef meat and $10 \%$ extruded wheat germ). Where, F2 had the highest panelists scores.Chemical, physical and characteristics.

\section{References}

Aitken, A. ; Casey, J. C. ; Penny, I. F. and Voyle, C. A. (1962). Effect of drying temperature in the 
accelerated freeze of prok. J. Sci. of Food Agric, 13(8):439-448.

Al-Hooti, S. N. ; Sidhu, J. S. ; Al-Saqer, J. M. and Al-Othman, A. (2002). Effect of raw wheat germ addition on the physical texture and objective color of a designer food (pan bread). Food Nahrung, 46 (2): 68-72.

Anae, R. G. and Josefphf, Z. (1996). Quality of Broiled Beef Patties Supplemented with Wheat Germ Total protein Flour. Journal of Food Science, 61 (2), 418-421.

A. O. A. C. (2005). Official methods of analysis of the Association of official Analytical Chemists, $178^{\text {th }}$ Edn (edited by W. Horwitz Washington, D.C.,U.S.A.

A.O.A.C. (1995). Official Methods of Analysis of the Association of Agricultural of official Analytical chemists (10th.ed). Washington- D.C. Pp. 758.

Brouce, B. ; Spiller, G. A. and Farquhar, J. W. (1997). Effects of a plant-based diet rich in whole grains, sun-dried raisins and nuts on serum lipototal proteins. Veg Nutr. 1(2):58-63.

El-Dash, S. (1985). Extrusion processing of broken rice. Ph.D Thesis Department Food Tech. Fac. of Agric. Cairo Univ. Egypt.

Egyptian Organization Standardization E. O. S. (2005). Minced Meat Mixed With Soybean Protein. E.S: 2097-2005, ICS : 67.120.10.

Fraser, G. E. ; Sabaté, J. ; Beeson, W.L. and Strahan, T.M. (1992). A possible protective effect of nut consumption on risk of coronary heart disease. Arch Intern Med., 152(7):14161424.

Gehan K. M. A. and Emara, M. M. T. (2010). Quality and Acceptability of Value-Added Beef Burger. World J. Dairy \& Food Sci., 5: 14-20.

Hedrick, H. B. ; Aberle, E. D. ; Forrest, J.C. ; Judge, M. D. And Merkel, R.A. (1994). Nutritive value of meat. Principles of meat Sci., 3: 289-298.

Kahlon, T. S. (1989). Nutritional implications and uses of wheat and oat kernel oil. Cereal Foods World, 34:872-875.

Kalpana, J. and Vali, S.A. (2009). Proximate composition of wheat germ based products $\mathrm{J}$. Dairying, Foods \& H.S., 28 (3and4) : 241-243.

Mizutani, T. and Hashimoto, H. (2004). Effect of grinding temperature on hydroperoxide and offflavor contents during soymilk manufacturing process. Food Sci., 69: 112-116.
Pearson, D. (1970). The chemical analysis of food. National college of reading. Wegbridge, Surry. J. and Chirchill, A.

Sahar R. Abd El-Hady (2012). Utilization of defatted wheat germ flour as nutrient supplement of biscuits J. Agric. Res. Kafer El-Sheikh Univ., 38(1): 238-253.

Sanchez-Alonso, I. ; Jimenez, E. A. ; Sura, F. and Borderias, A. J. (2007). Antioxidant protection of white grapa pomace on restructured fish products during frozen storage. Food Sci. and Technolo.,41(1): 1-9.

SAS Institute Inc (1996). SAS/STAT1 User's Guide, Version 8, SAS Institute Inc, Cary, NC.

Serdaroglu, M. and Degirmencioglu, O. (2004). Effects of fat level $(5 \%, 10 \%, 20 \%)$ and corn flour $(0 \%, 2 \%, 4 \%)$ on some properties of Turkish type meatballs (koefte). Meat Sci., 68: 291-296.

Soloviev, V. E. (1966). Meat aging In "Food Industry" Pub., (Moscow) pp: 53-81, 82 -164, $242-303$.

Spiller, G. A. and Jenkins, D. J. A. (1992). Effect of a diet high in monounsaturated fat from almonds on plasma cholesterol and lipototal proteins. J. Am. Coll Nutr., 11, 126-130.

Suderman, D. R. ; J. Wiker and F. E. Cunningham, (1981). Factors affecting adhesion of coating to poultry skin. effects of various protein and gum sources in the coating composition. Food Sci., 46: 1010-1011.

Supat, C. ; Kamolwan, J. and Anuvat, J. (2008). Effect of Total protein Content and Extrusion Process on Sensory and Physical Properties of Extruded High-Total protein, Glutinous RiceBased Snack. Kasetsart J. Nat. Sci., 42 : 182 190.

Turhan, S. ; Temiz, H. and Sagir, I. (2007). Utilization of wet okra in low-fat beef patties. Muscle Foods, 18: 226-235.

Yue, X. u. (2001). Perspectives on the 21st century development of functional foods. Bridging Chinese medicated diet and functional foods. International J. Food Sci. and Technol., 36: 229242.

Winton, A. K. and Winton, R. B. (1958). Okoloff magnesium oxide distillation volumetric method. The Analysis of Food. P., 848, J. Wiley. New York and Chapman, London. 
